\title{
EMPLACEMENT OF IDEAS. THE DEVELOPMENT OF GEOGRAPHICAL THOUGHT IN BRAZIL IN THE EARLY 20th CENTURY
}

\author{
LIA OSORIO MACHADO ${ }^{1}$
}

\begin{abstract}
This paper looks at the circulation of modern geographical ideas in Brazil. The focus is on the relationship between geographical source models and the target model of domestic modernization. Three corresponding 'mechanisms' provided the translation from one to the other: gradualism, adaptation and essentialism.
\end{abstract}

Key-words: Circulation of geographical ideas, source model, target model, Brazil.

Résumé: L'EMPLACEMENT DES IDEES. LE DEVELOPPEMENT DE LA PENSEE GEOGRAPHIQUE AU BRESIL AU DEBUT DU XX ${ }^{\mathrm{e}}$ SIECLE - L'article analyse l'arrivée au Brésil vers la fin du XIX ${ }^{\mathrm{e}}$ siècle, dans la période postérieure à la proclamation de la République, des idées géographiques mises en circulation en Europe et aux Etats-Unis. L'accent est mis sur les mécanismes de correspondance entre les modèles-source et les modèle-but de modernisation du pays. Nous considérons particulièrement trois mécanismes de cette translation: échelonnement, adaptation et essence.

Mots-clés: Diffusion des idées geógraphiques; modèle-source, modèle-but, Brésil.

Resumo: As Ideias no Lugar. O Desenvolvimento do Pensamento Geográfico no BRASIL NO INÍCIO DO SÉCULO XX - Este trabalho trata da transposição de ideias geográficas elaboradas na Europa e nos Estados Unidos no final do século XIX e sua circulação no Brasil nas décadas seguintes à proclamação da República. Para esta transposição concorreram 'mecanismos' de correspondência entre os modelos-fonte e o modelo-meta de modernização do país. Três desses mecanismos podem ser relacionados ao pensamento geográfico: gradualismo, adaptação e essencialismo.

Palavras chave: Circulação de ideias geográficas, modelos fonte, modelo meta, Brasil.

\footnotetext{
1 Universidade Federal do Rio de Janeiro. Rua João Zaneti, 31/202. 22621030 Rio de Janeiro, Brasil.

Tel.: 493 6092; Fax: 270 7773; E-mail: liamch@acd.ufrj.br
} 
Modern geographical ideas were introduced in Brazil in the context of a heated debate over the nature of the country's social, institutional and physical environment. At the core of this debate was the issue of modernizing a profoundly hierarchical and conservative society, grappling with the changes that had brought about the end of the monarchical system and of slavery.

The verbal battles were not neat and "mobility" in the positions of both "conservatives" and "progressives" was frequent. Broadly, however, two main groups can be identified. The conservatives argued that the end of the old system and the establishment of a Republican regime (1889) had endangered social-institutional stability thus opening the way for territorial secession, social conflict and worse, massbased democracy. Ideas that nurtured conflict with the inherited order would amplify social discontent and aggravate regional disparities. The "progressive" group contested that the perils of modernization could be avoided or curbed by the adoption of reformoriented social theories and a unifying ideology of nation-building.

While the introduction of geographical ideas can be traced to those intellectuals sharing a belief in the philosophy of progress, their emplacement shows a blend in with critical aspects of conservative thought. The period we are concerned with here covers the four decades that followed the onset of the republic during which sucessive thrusts of geographical ideas can be identified.

\section{THE EMPLACEMENT OF MODERN GEOGRAPHICAL THOUGHT}

By the end of the nineteenth century Intellectual life in Brazil can best be described as provincial and mostly dependent on the international centers of diffusion. In other words, ideas circulated only one way. There were no universities, only the schools of medicine, law and engineering. Learned culture had been drawn either from the Portuguese background or from French, Italian, German and Anglo-saxon sources. Intellectual specialization was minimal and the intellectual was a sort of specialist in generalities, inclined to an idealized description of his mission in domestic society. The anxiety and curiosity that moved them found their expression in the rhetorical evocation of ideas rather than in empirical research or through methodical discourse.

Such an unflattering albeit realistic evaluation of intellectual life at the onset of the Republican regime has tainted the historical record of modernization ideas in Brazil up to the present time when it is still a commonplace charge that past and present social scientists have continuously misplaced ideas, that are not only foreign but can be damaging to the domestic situation because of their contempt for the country such as it was (is). There is a qualified truth in this statement as far as it describes a certain kind of behaviour. On the other hand, it is debatable the implicit assumption that intellectuals are independent of domestic conflicts and capable of conceptual autonomy whatever the actual conditions of the society that has bred them.

The need to contend with the problem of space, or rather man in a space not yet subdued by modern civilization fast became a major issue for many reformers. This 
was not immediatly related to geography but to the host of 19th century social theories and scientific ideologies of progress. Thus, when modern geographical ideas began to circulate, they did so as part and parcel of "ideological conglomerates" already in place.

In figure 1, for presentation purposes, the geographical source "models" of thought circulating in Brazil between 1889 and 1930 have been arranged in a linear fashion instead of the more realistic network form.

In the lower section of the diagram, we have placed the Brazilian intellectuals deemed responsible for the diffusion of each model, followed by the year of publication of their writings. All of them were state-employees, close to the governmental elite, and one of them (Oliveira Viana) became a powerful figure in the Vargas dictatorship (1937-1945). The foreign 'geographer(s)' they used as reference have also been inserted, followed by the year of publication of the particular writing we assume to be the source since bibliographical references are rare.

In the upper section of the diagram, geographical source models are linked to some of the "ideological conglomerates" that we have been able to identify. These are represented by name, followed by the date of the (probable) bibliographical source that was used in Brazil. Not all of them are nominated in the selected texts so names usually associated to the ideas found in the texts have been added.

Our contention is, first, that foreign source models of thought, geographical or otherwise, were used as guides, to suggest ideas about dealing with a complex social situation, but they were also used as a sounding-board for both 'conservatives' and 'progressives' as they organized themselves around a modernization agenda. That the discussion of domestic-bred problems had to be displaced to foreign intellectual ground indicates how tenuous and uncertain was their grasp of the country's grim realities.

In the course of reinterpretating (thus emplacing) source models and establishing the target model of domestic modernization, some corresponding 'mechanisms' provided the translation (HOLLAND, 1998). At least three of them can be related to geographical thought: gradualism, adaptation and essentialism. In the following sections, we will attempt a brief account of this relationship.

\section{THE GRADUALIST APPROACH TO CHANGE: "SOCIAL GEOGRAPHY"}

Among the many theories of progress available at the time, positivism, spencerianism and racist theories all had a profound effect in Brazilian intellectual life and in the conception of reform policies. Political ideas derived from these theories, mainly those with psychological and medical overtones (Hippolyte Taine, Gustave Le Bon, Gabriel Tarde) were also prominent. 


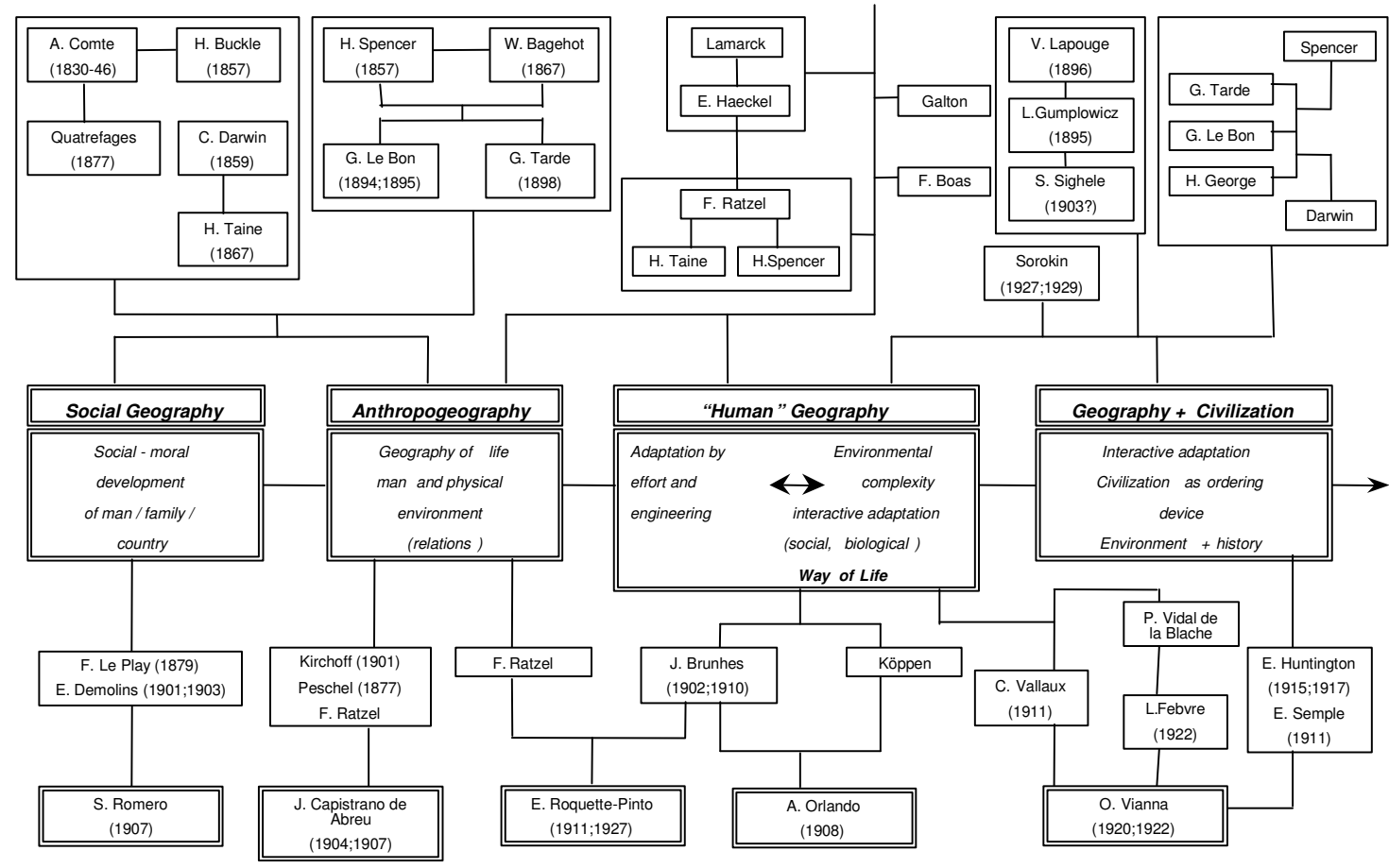

Fig. 1 - Geography and "ideological conglomerates" in Brazil (c. 1890-1930)

Fig. 1 - Geografia a “conglomerados ideológicos” no Brasil (c. 1890-1930) 
Since the 1870s, domestic issues had led many intellectuals, both "conservatives" and "progressives", to the positivist philosophy of Auguste Comte and later on, to Emile Littré (COSTA,1964). Republican and anti-slavery activists found in Comte's criticism of the Roman Catholic Church, slavery and the monarchy their own agenda for change. But the positivist principle that progress follows natural laws of evolution also appealed to conservatives, as did its corollary, the maintenance of hierarchy and order. Unlike other Latin American countries where positivism was associated to a more 'revolutionary' call for change (NACHMAN, 1977), positivism in Brazil reinforced a gradualist approach to reform.

The geographical ideas of Frédéric Le Play and his one-time disciple, Edmond Demolins were first applied to the Brazilian situation by a very influential intellectual at the time, Silvio Romero (1851-1914). A lawyer, literary critic and political essayist, Romero struggled all his life with the question of racial and environmental conditions for progress. This had led him, first, to the writings of Hippolyte Taine and Henry Buckle.

Romero accepted Buckle's indictment of tropical habitats but only in the sense that it would demand a greater effort of the inhabitants to master the environment. $\mathrm{He}$ found Buckle misinformed about the geography and climate of Brazil but, he added, so was the Brazilian ruling class and fellow intellectuals who ignored the country's environmental diversity and problems. While the ruling class was no better then parasites, living off the State, the latter refused to look 'inward', assuming an urban perspective that was misleading in face of the rural character of the Brazilian population.

By the 1890s, Romero had became a staunch supporter of spencerism. Spencer's evolutionary laws, he wrote in his book (Doutrina contra doutrina: o evolucionismo e o positivismo no Brasil, 1895), took into account 'internal' [organic] conditions for change while positivist laws held an 'external' [natural laws] viewpoint that favoured conservative thought. Spencer's organic and evolutionary theory of society showed the way to economic progress: an orderly but dynamic industry-led reform would generate greater differentiation and closer organic unity, more specialized functions and integrated action. In the spencerian critique of the state Romero also found support for one of his pet-ideas, the need for state-reform.

It has been suggested that positivism and spencerism have more in common then has generally been acknowledged. For one, the anti-statism which helped Spencer make his case for individualism can also be read as a need of authoritarian, even coercive orientation of the social body (Schlanger, 1971: 167), a possibility that moves Spencerians closer to the tutorial state defended by positivists. Another point of intersection could be a certain convergence of evolutionist and positivist classification systems, for instance, the role played by hierarchical order (TORT, 1989: 359). Both remarks are helpful in view of the embrication of positivist and spencerian evolutionist thought in Brazil and elsewhere.

In O Brasil Social (1907), Romero starts with a brief, rhetorical discussion of Le Play's multiscaled method of analysis and its pertinence to the Brazilian situation. Then he proposes eleven social-geographical zones according to "the nature of the work" 
done by its inhabitants. The conclusion is pessimistic for in each zone Romero finds that economic activities had disrupted family relations and had not been able to organize labour. The natural milieu did not help, for it punished those who worked and gratified those who did not. The Brazilian society is a [sic] societé à formation communautaire ébranlée. It had evolved from a (colonial) patriarchal-absolutist type of family to disorganised patriarchal families. Romero then turns to Spencerian ideas. Such a process of increasing instability was a consequence of the long-standing hereditary landholding system that had left the oligarchic social structure untouched. Abolition had worsen instability and disorder by leaving ex-slaves to their own means in rural and urban areas. Only a particularist (individualistic) social formation could effectively change this situation through entrepeneurship, industry and the toppling of oligarchic rule.

If we can assign to Silvio Romero the formal introduction in intellectual circles of the notion of "social geography" which made him a reference for later studies, he was not alone in the pursuit of environmental theories to contend with the flow of racist theories coming in the wake of scientism and doctrines of progress.

\section{ADAPTATION AND THE ETHNOGRAPHIC APPROACH: ANTHROPOGEOGRAPHY}

All the intellectuals mentioned here were involved at one time or another in a ferocious debate over Brazil's 'racial stock'. Indeed, most of them were mulattos. Both Brazilian and foreign scholars have written extensively about the subject and we will not attempt to retell this story. Instead, we shall focus on how geographical heuristics helped to shift emphasis away from race but also from the physical environment by giving explanatory status to the relations between them in a given territory.

Since the 1870s, Taine, Haeckel, Novicow, de Quatrefages, to name but a few, were frequently cited in political and scientific essays. Monism was a favourite catchword, and the followers of the "haeckelian variant of evolutionism" far outnumbered those of the "spencerian variant". Unexceptionally, for Haeckel's optimistic view of progress, his rhetorical treatment of Darwinian concepts, the refusal of any dualism between natural and cultural phenomena, in short, "social lamarckianism", has been found to be appealing to both conservative and progressive thought in very different national contexts (CAPEL, 1981; BERDOULAY, 1981; GÓMEZ MENDOZA et al., 1982; LIVINGSTON, 1992; RUPP-EISENREICH, 1992; LANDUCCI, 1992).

Lamarck and Darwin were seldom nominated in texts. Nonetheless, terms as "adaptation", "inheritance of aquired characteristics", "struggle for life", "natural selection" or "survival of the fittest" were freely employed, usually in the context of evaluations of race, the national character and the geographical milieu. At the end of the 19th century, groups and individuals were still labeled in terms of their affiliation to one or another evolutionary alternatives: "spenciarian evolutionists"; "haeckelian evolutionists"; "transformists"; "darwinists". None of these labels was attached to the scholar who first mentioned F.Ratzel's anthropogeography in a published text. 
João Capistrano de Abreu (1853-1927) was a self-taught historian who had helped organize the historical records of the National Library, where he worked during most of his life. A firm follower of the positivist credo in empirical research, he had come to grips with the realities of the Brazilian's confrontation with his habitat in an original study of the colonial settlement system (1889). An exception among his francophile colleagues, Capistrano was familiar with the work of Leopold v. Ranke and of Oscar Peschel, having translated several German geographical books, as Albert Kirchoff's Man and the Earth (Leipzig, 1901).

In a short article meant for the general public (A Geografia no Brasil, written 1901; published, 1904), Capistrano distinguished the practice of Brazilian geographers, which consisted in compiling endless lists of physical features and places to be memorized by students, from the scientific practice of foreign naturalists, ethnographers, geologists and geomorphologists in Brazil. However, the latter had ignored human society. By placing man and his lifeforms in the physical environment, Ratzel had changed the natural sciences and founded 'modern scientific geography'. Ratzel's idea that differences in the evolution of ethnic groups were more relevant then geographical unity to national politics could have inspired Capistrano, later on, to write the history of Brazilian ethnic groups in terms of environmental diversity.

The ethnographic approach could work well against racial determinism but it was not particularly new to Brazilian intellectuals, nor was monism and the notion of milieu. More innovative was the geographical heuristics proposed by anthropogeography. Ratzel's environmental holism enclosed and subordinated its opposite, the individual/ethnic component not in an abstract bounderless world but in delimited territories. In this sense it was a contextual thought even if the cosmic milieu stood out as the main referent. Thus, the influence of climate over human settlement was tempered by the contention that climatic influence was not the same in every stage of human development, or that work and permanence was the greatest defense against climatic influences. Also relevant to those who argued against racial determinism was Ratzel's adherence to anthropological theories which stipulated that people is a product of the land they inhabit, hence more apt [adapted] than any other to live where the land had biologically perfected them.

The use of geographical heuristics to contend with racial pessimism at least partially explains why intellectuals, and scientists, became increasingly interested in anthropogeography (MACHADO, 1995). Among the latter we find Edgard RoquettePinto (1884-1954).

The correlation between historical facts and the geographical character of a region is the greatest contribution of anthropogeography to science, Roquette-Pinto stated in a 1912 article (O Brasil e a Anthropogeografia). It is also essential to nations because it beckons them to study the land, plants, animals and inhabitants of their country. Ratzel's ethnographic approach, he continues, led him to see the uneven distribution of racial types as a consequence of the relations between land and historical constraints. In Brazil, for instance, higher density of afro-americans could be found in old plantation and mining zones. Accordingly, he distinguishes three ethnographic zones in the 
Brazilian countryside: the caboclo [indian mestizzo] zone in the Northern parts; a second zone, of African influence, covering the Atlantic seaboard and the mining areas in the backlands; and the zone of European influence, to the South of Rio de Janeiro. Following the teachings of Jean Brunhes, he adds, each ethnic group should be studied in their precise geographic area.

By the 1920s, Roquette-Pinto's enthusiam with anthropogeography had not waned but he had gone on to the cultural-historical ideas of Franz Boas and to eugenics. Evaluating the intellectual climate of the time (Seixos Rolados,1927), he states that the concept of selection had lost its cutting edge, the ferocious antagonism of the first darwinians being gradually replaced by the ecological approach, which meant that the Lamarckian principle of organic adaptation to the environment had finally prevailed.

A doctor and anthropologist, Roquette-Pinto was a member of the Rondon expeditions (1907-1913) to the Western frontier, later publishing a highly cited ethnographic survey of Indian and caboclo population. He worked at the Museum of Natural History which he headed for many years; in 1927, he organized the first Brazilian Congress on Eugenics.

\section{INTERACTIVE ADAPTATION AND HUMAN GEOGRAPHY}

There was yet another aspect to the modernization debate that nourished the discussions over race and eventually, the environment. Work (in the sense of labour) was, of course, a key issue for a nation that had recently got rid of slavery. It is present in Romero's use of Le Play and also in Roquette-Pinto's approach to Ratzel. To understand the status of labour in different parts of the country, how it fared against the environment or, conversely, how the environment affected their capacity to work, were very concrete issues. Indeed, enclosed in the "adaptation" mechanism was the question of how "adaptable" was the Brazilian population to work and effort previously associated to slave labour. Moreover, as amply discussed in pertinent literature, adaptation was a catch-word for those who wished to avoid what they understood to be the political implications of darwinist concepts.

It has been contended how important to the scientific project of Vidal de La Blache was the incorporation of the neo-lamarckian idea of adaptation as an active process of organisms, or the role he accorded to effort, human initiative and cooperation, and how neatly he integrated some of Darwin's ideas (BERDOULAY and SOUBEYRAN, 1991). References to Vidal de La Blache are very rare, however, in Brazilian texts. Only in the 1910s does his name appear, but even then, no clear distinction was made between his ideas and those of anthropogeography.

As mentioned above, one of Vidal's disciple was well known since the 1900s. Jean Brunhes' role in the development of geography in Brazil has yet to be studied, his book La Géographie Humaine (1910; last edition, 1954) was still used by teachers and students in the 1960s (in French!). Brunhes is considered one of the main introducers of anthropogeography in France, although it has been alleged that he distanced himself later on from the environmental determinism commonly associated to Ratzel's proposal 
(BROC, 1977). For the Brazilian intellectuals who used his name and his ideas in the late 1900s, thus before the publication of La Géographie Humaine, Brunhes came across as an anthropogeographer who emphasized the role of effort, work and industry in human adaptation to the physical environment.

"The physical environment by itself is not everything: besides soil, climate, rivers and mountains, temperature and rainfall, plants and animals, we must look into man's activities, for he is the one who cultivates plants, domesticates animals, builds tunnels and irrigates the land, modifies the reciprocal effects of temperature, winds and rainfall, and increasingly adapts natural energy as steam and electricity, to his own physical, moral and intellectual needs". To describe human modifications of the natural order and use it as a statement can be interpreted as part of a rhetorics specially directed to the edification of work and effort, a project that some reformists deemed as strategic at the time. It can also help to explain the increasing popularity of Jean Brunhes' quasipedagogical approach to the use of local resources within the framework of "scientific" environmentalism.

The article from which this citation was extracted, As zonas geográficas brazileiras (1908), was written by Arthur Orlando and published in the Journal of the Historical-Geographical Institute of São Paulo. Orlando (1858-1916) was a lawyer and man of letters who became interested in climatic theories late in life. He was a disciple of Silvio Romero and a spencerian himself. The article surveys Silvio Romero's classification of social-geographical zones and an earlier attempt by the engineer Andre Rebouças to distinguish agricultural zones according to the commercial use of plants and animals (1889), after which Orlando proposes a new approach and classification scheme, based on Köppen and Brunhes.

Köppen's method of climatic classification took into account domesticated plants and animals formations which helped him see the diversity of environments in each climatic zone and and how levels of civilization interfered in their development. Orlando was referring to the first attempt of the German climatologist, Wladimir Köppen, to develop the system of classification that bears his name, published in 1900 (complete editon, 1918). Köppen, wrote Orlando, had established that climatic zones were organic wholes, determined by the physical and biological elements and by the activities of man. Each particular combination creats a landscape of habitat where the life forms develop. Köppen's ecological approach, his idea of a biological optimum were essential for landscape taxonomy. Orlando indicates Ch.Flahaut as his source for the Köppen classification.

Jean Brunhes' method was similar, Orlando said, but his emphasis was on vegetation physiognomy. The reason was that plants, rooted in soil, are subordinated more than any other living form to the environment, occupying less extensive areas because of their fixity. Thus, according to Brunhes, plant formations constituted "small wholes" that revealed the decisive effect of the milieu. No rigorous classification of geographical zones was possible due to the lack of studies about plant formations in Brazil, so Orlando suggests a broad distinction of three geographical zones based on the dominant vegetation physiognomy: the sertão (arid backlands); the campos (grasslands) and the 
tropical forest. Each of them presented a different economic and "intellectual" (cultural?) situation.

Years later, Orlando's attempt at distinguishing geographical zones in rural Brazil was taken up and developed by a much more prolific writer, lawyer and would-be historian, Francisco de Oliveira Viana (1885-1951). Viana's life-long ambition was to be the interpreter of Brazilian realities, an ambition he nearly acheived in the period between the wars.

In a historical study of the settlement process in Southeastern Brazil (As Populações Meridionais, 1920), Oliveira Viana sought to apply the ideas of anthropogeography and anthroposociology. His idea was to prove how wrong was the conception of the Brazilian people as an homogeneous mass. There were three great regions in Brazil (the sertão; the grasslands; the forest); each had endured different historical and social pressures, generating specific social types and a diversity of habitats. Then Viana makes his point: the forestlands of Southeastern Brazil was the gravitational core of national politics since Independence, an outcome of the geographical contiguity of the main agriculture ecumene to the core of national government. It was clear that this situation gave their inhabitants the preponderance over the other two regions, so they were the ones selected to organize and direct the formation of Brazilian nationality. For Brazil was not yet a nation, it was an incoherent, desintegrated, undisciplined, unstable mass of people, with very loose ties to the land.

The spencerian formulation of evolution as a process from an indefinite, incoherent homogeneity to a definite, coherent heterogeneity was wrong. In theory, as postulated by Gabriel Tarde, the opposite was true. In practical terms this meant that intellectuals should stop thinking that the Brazilian society would follow in the steps of European and North American societies.

Social types were not fixed as social environment was fixed. The mestizzo population was still a majority. Unfortunely, as anthropological laws had proven, they show a tendency to inherit the worst and not the best of their ancestors (Gobineau). Selective processes, however, would take care of this problem by elimination of inferior social elements (Vacher de Lapouge) and the white population would finally predominate. Therefore, the real challenge was to modify the social environment.

\section{GEOGRAPHICAL ESSENTIALISM, CLIMATE AND CIVILIZATION}

In the introduction to the official 1920 census, later published as a book (Evolução do Povo Brasileiro, 1922), Oliveira Viana starts with a critical overview of Spencer, Haeckel and the positivists and then expands his ideas on the historical evolution of Brazil's society, race, and institutions. The first two parts of the account, society and race, relies heavily on the anthroposociology of Lapouge and the political-psychological theory of Gustave Le Bon.

The last part of the book, the evolution of political institutions, is where, according to Viana, he shows the importance of geography in Brazilian history. First, there was the problem of an extensive territorial base very sparsely settled, and minumum social 
and political circulation. Population nodes were isolated, their survival dependent of local resources and the power of clans. This he called the "desintegrative action of geographical factors", responsible for the fragmentation of governmental power. Second, geographical factors had caused the differentiation of the people, by forcing them to adapt to local conditions and create types of political organization suited to regional particularisms. Third, social factors had also contributed to the heterogeneity of primitive organisation in Brazil because of ethnical and political diversity. Thus, the struggle was not between individuals or groups, the struggle was against the centrifugal forces, represented by geographical factors and its historical consequences, parochialism and localism. The new republican regime was in the right path when it stimulated centripetal forces (colonization and development of means of communication). By token, this would strengthen the central government and national unity.

For the second edition (1932), Oliveira Viana adds an introductory chapter entitled "The modern concept of social evolution", where he enlarges his discussion of geographical ideas. Following Gabriel Tarde, Viana mantains the idea that there is no "linear evolution" but a plurality of evolutionary paths in some measure independent one from the other. Equally important is the role of random events in history, as discussed by the French historian Henri Berr.

Human groups have many things in common due to the encompassing force of civilization but this does not imply that they are identical. Such an idealistic belief has bred the unhappy tendency to imitate foreign institutions instead of developing organic policies based on national peculiarities. Foremost in explaining the immense variation in evolutionary paths is the role of the cosmic milieu. In place of Ratzel's geographical fatalism, the "possibilism" of Vidal de La Blache and his disciples assigns to man the force of intelligence to counter the brute force of environmental determinism which reduces him to a mechanical device. Nevertheless, man can never be entirely free of environmental influences, as even Lucien Febvre had to concede.

The message of this passage is obvious enough but it serves to show Viana's attempt to integrate Lucien Febvre re-interpretation of Vidalian thought (La Terre et l'évolution humaine, 1922 with a preface by Henri Berr) without changing the gist of his argumentation. This is clear when he immediatly turns to the ideas of Ellsworth Huntington, cited alongside Woodruff, Hellpach, Ellen Semple and de Courcy Ward. Huntington had proven, Viana wrote, how susceptible human aggregates were to minor meteorological variations. These variations were responsible for local differentiations that would in time spread and encompass the whole social structure. The subtle play of these variations established irreducible differences among human aggregates even when they shared the same civilization. Is Oliveira Viana worried by Huntington's indictment that racial and climatic conditions had left "the tropical part of Mankind far in the rear" [of civilization]? Not at all. Both the tropical environment and the tropicalization of so many exotic races in Brazil is more then anything else a practical problem, he concludes; its solution will not come from foreign sources but from a national program of political reforms, etc. 


\section{FINAL REMARK}

Is it worthwhile to retrace what people thought and wrote about geography and social problemas so long ago? Right now Brazil has enough social and economic challenges to address, so this could be considered as a futile and worse, necropholic attempt to "awaken the dead" (BARNETT, 1995). Old ideas, like bad ideas, however, die hard. To exemplify. Last year, a very respected scholar used 650 pages to explain the wealth and poverty of nations by asking the big question, why some are so rich and some so poor? (LANDES, 1998). He starts this clearly provocative book with geography. Ellsworth Huntington, he writes, studied the ways that geography, especially climate, influenced human development. But Huntington gave geography a bad name by simply echoing the tradition of moral geography. The reason why geography "emits a sulfurous odor of heresy is that it tells an unpleasant truth, namely that nature like life is unfair, unequal in its favors; further, that nature's unfairness is not easily remedied. Geography, in short, brings bad tidings, and everyone knows what you do to that kind of messenger". Culture, Landes adds, also makes a difference and Western culture has divided the world in two halves: "the West and the Rest". The World Bank took up the challenge and last year a whole session of an international seminar was dedicated to the topic "Geography as destiny", to discuss the influence of geography in national development. Whatever the fate of this revival the question remains as to why certain ideas and certain authors seem to able to return to the future.

\section{BIBLIOGRAPHY}

BARNETT, C. (1995) - Awakening the dead: who needs the history of geography? Transactions Institute of British Geographers, NS 20, Londres: 417-419.

Berdoulay, V. (1981) - La formation de l'École Française de Géographie. Bibliotheque National,C.T.H.S., Paris.

Berdoulay, V.; O. Soubeyran (1991) - Lamarck, Darwin et Vidal: aux fondements naturalistes de la géographie humaine. Annales de Géographie, 561-562, Paris: 617-634.

BROC, N. (1977) - La géographie française face à la science allemande (1870-1914). Annales de Géographie, 473, Paris: 71-94.

CAPEL, H. (1981) - Filosofía y ciencia en la Geografía Contemporánea. Barcanova, Barcelona.

CostA, J. C. (1964) - A History of Ideas in Brazil: The Development of Philosophy in Brazil and the Evolution of National History. University of Califonia Press, Berkeley.

Gómez MendozA, J.; J. MuÑoz; N. ORTEGA (1982) - El pensamiento geográfico. Alianza Editorial, Madrid.

Holland, J. H. (1998) - Emergence. From Chaos to Order. Addison-Wesley, Reading (Mass.).

LANDES, D. S. (1998) - The Wealth and Poverty of Nations. Why some are so rich and some so poor, W. W. Norton, New York.

LANDUCCI, G. (1992) - Darwinisme et nationalisme en Italie. In P.TORT(ed). Darwinisme et Societé, PUF, Paris: 285-351. 
LIVINGSTON, D. N. (1992) - The Geographical Tradition. Blackwell, London.

MACHADO, L. (1995) - Meio tropical, espaços vazios e a idea de ordem. In I. CASTRO et al., Geografia.Conceitos e Temas, Bertrand, Rio de Janeiro: 309-353.

NACHMAN, R. G. (1977) - Positivism, Modernization and the Middle Class in Brazil. Hispanic American Historical Review 57(1): 1-23.

RUPP-EISENREICH, B. (1992) - Le darwinisme social en Allemagne. In P. TORT (ed). Darwinisme et Societé, PUF, Paris: 169-221.

SCHLANGER, J. (1971) - Les métaphores de l'organisme, L'Harmattan, Paris, reimp. 1995.

TORT, P. (1989) - La raison classificatoire. Aubier, Paris. 